\title{
Induction and Maintenance of Amenorrhea in Transmasculine and Nonbinary Adolescents
}

\author{
Jeremi M. Carswell* and Stephanie A. Roberts
}

\begin{abstract}
The treatment of persistent uterine bleeding in those patients who identify as transmasculine or nonbinary is often straightforward, but can be difficult in a subset of patients. This article reviews the physiology of the normal menstrual cycle and the hormonal influences on the endometrium, and then explores options for the treatment of persistent bleeding for people both already on testosterone and for those who are either not ready for or who do not desire testosterone.
\end{abstract}

Keywords: secondary amenorrhea; progestins; endometrium; uterine bleeding; gonadotropin releasing hormone analogs; testosterone

\section{Introduction}

Uterine bleeding can be a source of distress in those for whom their gender identity is incongruent. Clinical experience shows that depressive symptoms and selfharming behaviors may peak during menstrual bleeding. Menstrual cycling is typically suppressible with hormonal therapy, although in a significant proportion of individuals it may persist. This review article addresses the most common treatment options for persistent uterine bleeding.

A normal menstrual cycle requires an intact hypothalamic-pituitary-gonadal axis and adequate estrogen and progesterone at the level of the endometrium. The hypothalamus secretes gonadotropin-releasing hormone $(\mathrm{GnRH})$ in a pulsatile fashion; this causes release of luteinizing hormone (LH) and follicle-stimulating hormone (FSH) from the pituitary gland, which promote ovarian follicle development and estradiol secretion. At the level of the endometrium, estrogen's primary action is to promote growth while progesterone limits proliferation by stabilizing the glands and halting mitotic division. ${ }^{1}$ Local uterine factors whose contributions are less clearly defined, including prostaglandins, nitric oxide, and others, are likely responsible for the variability in flow, volume, and duration of bleeding. ${ }^{2-4}$ The rapid decline in both progesterone and estrogen in the absence of a fertilized egg is the trigger for shedding of the lining of the uterus, but only if estrogen has been present. ${ }^{1}$ The anovulatory uterus may be susceptible to erratic bleeding, which is thought to be due to insufficient levels of progesterone.

When considering hormonal manipulation to halt menstrual cycling it is important to obtain a menstrual history. A typical menstrual cycle is between 25 and 35 days, although just after menarche the range may be from 21 to 45 days. ${ }^{4}$ Endometria of patients with menorrhagia may require a high dose, local form of progestogen (e.g., intrauterine device), whereas normally cycling patients may respond to a continuous low-dose oral progestin. ${ }^{2}$ Additionally, when counseling patients it is critical to remember that there will be individual differences, even between people with regular menstrual cycles. Persistent bleeding despite adequate therapy should prompt consideration of alternate etiologies, including coagulation defects, thyroid disease, structural abnormalities (e.g., endometrial polyps), infection, trauma, and/or pregnancy. ${ }^{5}$ 
We typically avoid giving any form of estrogen, as most often this is the hormone that most patients would like to avoid, however, the use of estrogen combined with progesterone is a highly effective way to stabilize the endometrium and avoid breakthrough bleeding; it remains a viable option for those who are not averse to taking it.

\section{Testosterone}

For those adolescents who have met criteria for genderaffirming hormone use, testosterone $(\mathrm{T})$ is typically highly effective for induction and maintenance of amenorrhea within 6 months of its initiation, although may be effective as early as 1 month. ${ }^{6}$ Greater than $90 \%$ of transmen using either biweekly intramuscular or weekly subcutaneous forms of testosterone achieve amenorrhea within 6 months (Table 1). ${ }^{6,7}$

Testosterone acts directly on the endometrium, causing both endometrial and vaginal atrophy as shown by examination of the endometria of transmen who had been on androgen therapy for at least 6 months. ${ }^{8}$ Histological analysis of endometrial samples of transmen on testosterone for at least 1 year is similar to that of postmenopausal women. Both groups expressed similar levels of Ki-67, a marker of endometrial proliferation. ${ }^{9}$ There is, however, controversy as some studies have shown an active endometrium and hypertrophic myometrium in some individuals. ${ }^{10}$

While the effects of testosterone on the uterus itself are fairly clear, less is understood about its effects on the hypothalamus and pituitary. Reports of unplanned pregnancies while on testosterone support a lack of inhibition of ovulation in at least some individuals. ${ }^{11}$

There does appear to be a dose-dependent amenorrheic response to $\mathrm{T}$, which supports a trial of increased dose or frequency in cases of persistent bleeding. An increase of dose or dose frequency was shown by Nakamura et al. to be effective in inducing secondary amenorrhea. ${ }^{6}$ The recommended therapeutic range for testosterone levels is $350-700 \mathrm{ng} / \mathrm{dL}^{12}{ }^{12}$ However in conditions in which the sex hormone binding globulin levels may be low (e.g., obesity and polycystic ovarian syndrome) total testosterone levels may appear subtherapeutic while free testosterone levels are in the normal range for adult males. Current guidelines recommend monitoring total testosterone levels only. ${ }^{12}$

\section{Progestogens}

Progestogens, comprised of natural, micronized progesterone and synthetic progestins, are an important class of medications for induction of amenorrhea in the transmasculine and nonbinary adolescent. They may be considered in the postmenarchal adolescent not yet ready for or desiring of masculinizing hormones, but may be less effective in inducting amenorrhea than combined oral contraceptive pills that contain estrogen. Progesterone and progestins are available in different formulations, including oral, injectable, implantable, and intrauterine (Table 2 ). In our practice we typically start with norethindrone or norethindrone acetate.

Progestogens exert most of their effects peripherally at the level of the endometrium primarily through changes in angiogenesis. Systemic forms at higher doses may also suppress the hypothalamic-pituitary-gonadal axis by inhibiting GnRH activity ${ }^{13}$ and therefore induce hypothalamic amenorrhea. Both forms counteract the effects of estrogen by inhibiting the proliferation of the endometrium and reducing the mitotic rate of the glands and stromal tissue, ${ }^{14-16}$ through reduction of the estrogen receptors on the glands. ${ }^{17}$ In normally menstruating women, exposure to a low-dose progestogen may cause

Table 1. Select Testosterone Formulations Available in the United States

\begin{tabular}{|c|c|c|c|c|}
\hline $\begin{array}{l}\text { Testosterone } \\
\text { formulation }\end{array}$ & How supplied & Typical adult dose & Typical max dose & Comments \\
\hline \multirow{2}{*}{$\begin{array}{l}\text { Testosterone } \\
\text { cypionate }\end{array}$} & 100 mg/mL (10 mL vial) & 100 mg q 2 weeks IM & 200 mg q 2 week (IM) & \multirow{2}{*}{$\begin{array}{l}\text { Excipient is cottonseed oil, allergic } \\
\text { reaction possible }\end{array}$} \\
\hline & $200 \mathrm{mg} / \mathrm{mL}(1 \mathrm{~mL}$ or $10 \mathrm{~mL}$ vial $)$ & $50-80$ mg weekly SQ & 100 mg weekly (SQ) & \\
\hline $\begin{array}{l}\text { Testosterone } \\
\text { enanthate }\end{array}$ & $\begin{array}{l}200 \mathrm{mg} / \mathrm{mL} \\
5 \mathrm{~mL} \text { vial }(5 \mathrm{~mL})\end{array}$ & Same as above & Same as above & $\begin{array}{l}\text { Excipient is sesame seed oil, allergic } \\
\text { reaction possible }\end{array}$ \\
\hline \multirow[t]{2}{*}{ Gel } & $1.62 \%$ (20.2 mg/pump press) & 20.25-81 mg daily & $103.25 \mathrm{mg} \mathrm{Q} \mathrm{AM}$ & \multirow{2}{*}{$\begin{array}{l}\text { Must be applied to upper } \\
\text { shoulders/back. Beware of } \\
\text { contact transfer }\end{array}$} \\
\hline & $\begin{array}{l}\text { or } 20.25 \text { or } 40.5 \mathrm{mg} / \text { packet } \\
1 \%(25 \text { or } 50 \mathrm{mg} / \mathrm{packet})\end{array}$ & $25-100 \mathrm{mg}$ daily & $100 \mathrm{mg}$ Q AM & \\
\hline Pellets & $\begin{array}{l}\text { Each pellet contains } 75 \mathrm{mg} \\
\text { testosterone }\end{array}$ & $\begin{array}{l}4-6 \text { pellets every } \\
3-6 \text { months }\end{array}$ & 6 pellets & $\begin{array}{c}\text { Each pellet releases about } 25 \mathrm{mg} \mathrm{T} \text {; } \\
\text { may last from } 3 \text { to } 6 \text { months }\end{array}$ \\
\hline Axillary gel & $\begin{array}{l}\text { Axillary gel } \\
30 \mathrm{mg} \text { per pump }\end{array}$ & $60 \mathrm{mg}$ (2 pumps) q AM & $\begin{array}{l}90-120 \mathrm{mg} \\
\text { (3-4 pumps) q AM }\end{array}$ & Applied like deodorant \\
\hline Patch & $\begin{array}{l}2 \mathrm{mg} / 24 \mathrm{~h} \\
4 \mathrm{mg} / 24 \mathrm{~h}\end{array}$ & $4 \mathrm{mg} / 24 \mathrm{~h} \mathrm{q} \mathrm{PM}$ & $8 \mathrm{mg} / 24 \mathrm{~h} \mathrm{q} P M$ & $\begin{array}{l}\text { May cut patches in half, } 10 \% \text { risk of } \\
\text { skin irritation }\end{array}$ \\
\hline
\end{tabular}

$\mathrm{T}$, testosterone. 
Table 2. Select Progestogens Available in the United States

\begin{tabular}{|c|c|c|c|c|}
\hline Active ingredient & Trade names & How supplied & Dosing patterns & Comment \\
\hline \multicolumn{5}{|l|}{ Oral } \\
\hline Norethindrone & $\begin{array}{l}\text { Micronor } \\
\text { Camila } \\
\text { Deblitane } \\
\text { Heather } \\
\text { Jencycla } \\
\text { Jolivette } \\
\text { Sharobel }\end{array}$ & $0.35 \mathrm{mg}$ tabs & Once daily & $\begin{array}{l}\text { "Mini-pill" for oral contraception. } \\
\text { Must be taken at same time of day }\end{array}$ \\
\hline Norethindrone acetate & Aygestin & $5 \mathrm{mg}$ tabs & Once daily ( $2.5-15 \mathrm{mg}$ daily) & May titrate up to effect \\
\hline $\begin{array}{l}\text { Medroxyprogesterone } \\
\text { acetate }\end{array}$ & Provera & $\begin{array}{l}2.5,5,10 \mathrm{mg} \\
\quad \text { tabs }\end{array}$ & Once or twice daily & $\begin{array}{l}\text { Dosing has ranged from } 20 \text { to } \\
80 \mathrm{mg} \mathrm{day}{ }^{19}\end{array}$ \\
\hline $\begin{array}{l}\text { Micronized progesterone } \\
\text { Injectable }\end{array}$ & Prometrium & $100,200 \mathrm{mg}$ & 100-200 mg nightly & Incipient contains peanut oil \\
\hline \multirow[t]{2}{*}{$\begin{array}{l}\text { Medroxyprogesterone } \\
\text { acetate }\end{array}$} & Depo-Provera & $150 \mathrm{mg} / 1 \mathrm{~mL}$ & & $\begin{array}{l}\text { Deep IM injection into gluteal or } \\
\text { deltoid muscle q } 12-14 \text { weeks }\end{array}$ \\
\hline & $\begin{array}{l}\text { Depo-SubQ } \\
\quad \text { Provera } 104\end{array}$ & $104 \mathrm{mg} / 0.65 \mathrm{~mL}$ & & $\begin{array}{l}\text { Anterior thigh or abdomen q 12-14 } \\
\text { weeks }\end{array}$ \\
\hline \multicolumn{5}{|l|}{ Intradermal } \\
\hline Etonogestrel & Implanon & $\begin{array}{l}68 \text { mg single } \\
\text { capsule }\end{array}$ & Active for 3 years & $\begin{array}{l}\text { Breakthrough bleeding common } \\
\text { initially }\end{array}$ \\
\hline \multicolumn{5}{|l|}{ Intrauterine } \\
\hline Levonorgestrel & $\begin{array}{l}\text { Mirena } \\
\text { Liletta }\end{array}$ & $52 \mathrm{mg}$ & May be left in for 5 years & $\begin{array}{l}\text { Insert within } 7 \text { days of onset of } \\
\text { menstruation }\end{array}$ \\
\hline
\end{tabular}

disturbances in endometrial angiogenesis and cause lowvolume irregular bleeding. ${ }^{2}$ Prolonged use typically leads to endometrial atrophy. ${ }^{18}$ Oral medroxyprogesterone has been used historically to suppress the hypothalamicpituitary-gonadal axis and may be a more cost-effective option in some areas compared with $\mathrm{GnRH}$ agonist (GnRHa). ${ }^{19}$ The progestin-only contraceptive pill norethindrone may inhibit ovulation in some women; although up to $40 \%$ of cis-females have been reported to continue ovulating. ${ }^{20}$ Intrauterine levonorgestrel may lead to partial suppression of ovulation, but thought to act more locally at the endometrium. ${ }^{21}$ Although ovulation may be disturbed to some extent, estradiol levels are normal limiting the concern for impact on bone health compared with injectable medroxyprogesterone. ${ }^{22}$

With any of the progestogens, irregular and unpredictable bleeding is relatively common and may lead to discontinuation of the agent, particularly in the first few months of treatment. This is due to vascular changes in the endometrium rather than hormonal fluctuation. ${ }^{23}$ Frequent and prolonged but light bleeding occurs in a large percentage of patients. ${ }^{1}$ When classified by histological samples (pseudodecidualization and reduction of mitotic index), the most potent progesterone is medroxyprogesterone acetate. ${ }^{24}$ There has, however, been concern about the long-term use of medroxyprogesterone acetate and bone health, first raised by Cundy et al. who reported a significant decrease in bone mineral density $(6.6 \%$ at the femoral neck and
$7.5 \%$ at the spine) compared with menopausal controls. ${ }^{25}$ Other studies have supported this finding. In a large population-based study in Washington, Scholes et al. reported a $2.2 \%$ difference at the spine and $2.5 \%$ difference at the femoral neck compared with premenopausal controls. Eighteen to twenty-one year olds, however, had the most impact to their bone mineral density, on average $10.5 \%$ lower compared with controls. ${ }^{26}$ This was a crosssectional study and length of use ranged from 1 to 33 months. Consensus statements issued from the World Health Organization, the American Society for Adolescent Medicine, and others do not recommend avoidance of this agent. They do recommend counseling on advantages and disadvantages. ${ }^{27-29}$

Adverse effects of progestins include bone health concerns and androgenic effects of lower high-density lipoprotein cholesterol, fluid retention, headaches, and mood disturbance. Natural progesterones' side effects are limited to fatigue and sedation ${ }^{30-32}$ and should be taken at bedtime. A major benefit to this class of hormone is that there is no increased risk for thromboembolic events; it is recommended for contraception by the WHO even in individuals with a history of thrombosis and vascular disease. ${ }^{33}$

For those minority of patients who are having continuous bleeding and are not averse to taking estrogen, a combination of micronized estrogen (Estrace $1.5 \mathrm{mg}$ daily) for 25 days combined with continuous low-dose micronized progesterone (100 $\mathrm{mg}$ daily) 
has been shown to control endometrial proliferation, although this does not fully suppress mitotic activity. ${ }^{14}$ This regimen may be more acceptable than a traditional combined oral contraceptive pill given continuously, which will achieve the same result. In practice, given its increased effectiveness over progestins in leading to menstrual suppression, a combined oral contraceptive pill may be amenable to some patients and is commonly used by some practitioners over progestins. Oral contraceptive pills containing first- and secondgeneration progestins have a higher androgenic profile and lower risk of venous thromboembolism and may be preferable preparations for this population compared with oral contraceptive pills containing later generation of progestins.

\section{Aromatase Inhibitors}

These agents inhibit Cytochrome P450 aromatase enzyme that converts testosterone to estradiol and androstenedione to estrone. This enzyme is active in peripheral tissues throughout the body, including skin, bone, brain, and adipose tissue. ${ }^{34}$ Aromatase inhibitors (AIs) are used most often in hormone receptor-positive breast cancer in postmenopausal women. ${ }^{35}$ They are also effective at increasing testosterone levels in cis-men. ${ }^{36}$ In the pediatric population they have been used in hyperestrogenic states such as McCune-Albright syndrome, hyperandrogenic states such as familial male-limited peripheral puberty, pubertal gynecomastia, short stature, and/or pubertal delay in cis-gender males. ${ }^{37}$

Third-generation AIs, including anastrozole and letrozole are the most potent, selective, and least toxic AIs available. These agents may be of particular benefit in the obese patient, as aromatase is highly expressed in adipocytes. In many obese trans-patients with low $\mathrm{T}$, increasing the $\mathrm{T}$ levels may only serve to be converted to estradiol in adipocytes. ${ }^{38}$ Although generally well tolerated, menopausal-like side effects may occur, including fatigue, headache, hot flashes, and vaginal dryness. The serum testosterone level is expected to increase and therefore there may be an increase in hematocrit, and decrease in high-density lipoprotein. In a growing adolescent there is a concern for adverse impact on bone health, decrease in height velocity, and delayed epiphyseal maturation. ${ }^{36}$

\section{Selective Estrogen Receptor Modulators}

These agents interact with intracellular estrogen receptors in target organs as estrogen receptor agonists or antagonists in a tissue-specific manner. ${ }^{39}$ Tamoxifen, the oldest member of this class, is a competitive inhibitor of estrogen at the breast, but an agonist in the endometrium. For this reason, there is a risk of endometrial hyperplasia, polyps, carcinoma, and uterine sarcoma as well as ovarian cysts, which is thought to be highest in postmenopausal cis-women. ${ }^{40}$ Other side effects may include menopausal-like symptoms and increased risk of thrombosis. ${ }^{39}$ For these reasons, these are not commonly used in the treatment of uterine bleeding in transmen.

Selective estrogen receptor modulators (SERMs) are typically used in infertility treatment, estrogen receptorpositive breast cancer, and in the prevention and treatment of osteoporosis in postmenopausal cis-women. ${ }^{41}$ In the pediatric population SERMs have been used successfully for gynecomastia in adolescent cis-males. ${ }^{42,43}$ It has been used with limited clinical experience to help induce amenorrhea (personal correspondence, Norman Spack), which was inspired by a small cohort of McCuneAlbright patients who demonstrated a reduction in vaginal bleeding. ${ }^{44,45}$

\section{GnRH Agonists}

GnRHa mimic the hypothalamic hormone GnRH; when given continuously they act as an inhibitor of the pituitary gonadotropins $\mathrm{LH}$ and $\mathrm{FSH}$; they also cause downregulation of the $\mathrm{GnRH}$ receptors on the pituitary gland, thus affecting the downstream products of LH and FSH, or gonadal steroids (testosterone and estrogen). In practice, this is a highly effective way to halt production of estradiol or testosterone. GnRHa are available in intramuscular 1-, 3-, and 6-month formulations, as well as an intradermal capsule that typically is effective for greater than 1 year.

GnRHa are typically used in pediatrics for treatment of central precocious puberty ${ }^{46}$; for adults they are used for the treatment of metastatic prostate cancer or other sex steroid-fueled malignancies. In the transgender population, they are commonly referred to as "puberty blockers" as they are used to halt and/or prevent development of secondary sexual characteristics of the assigned gender. ${ }^{12}$

Side effects are primarily local and related to the type of insertion used, although there are concerns about bone health as this has been shown to decline in both transgirls and transboys on GnRHa. ${ }^{47}$ When used in a precocious puberty population, there seem to be no long-term consequences on fertility or bone health. ${ }^{48}$ In an individual who has already experienced puberty, and sex steroids (gender affirming or endogenous) are 


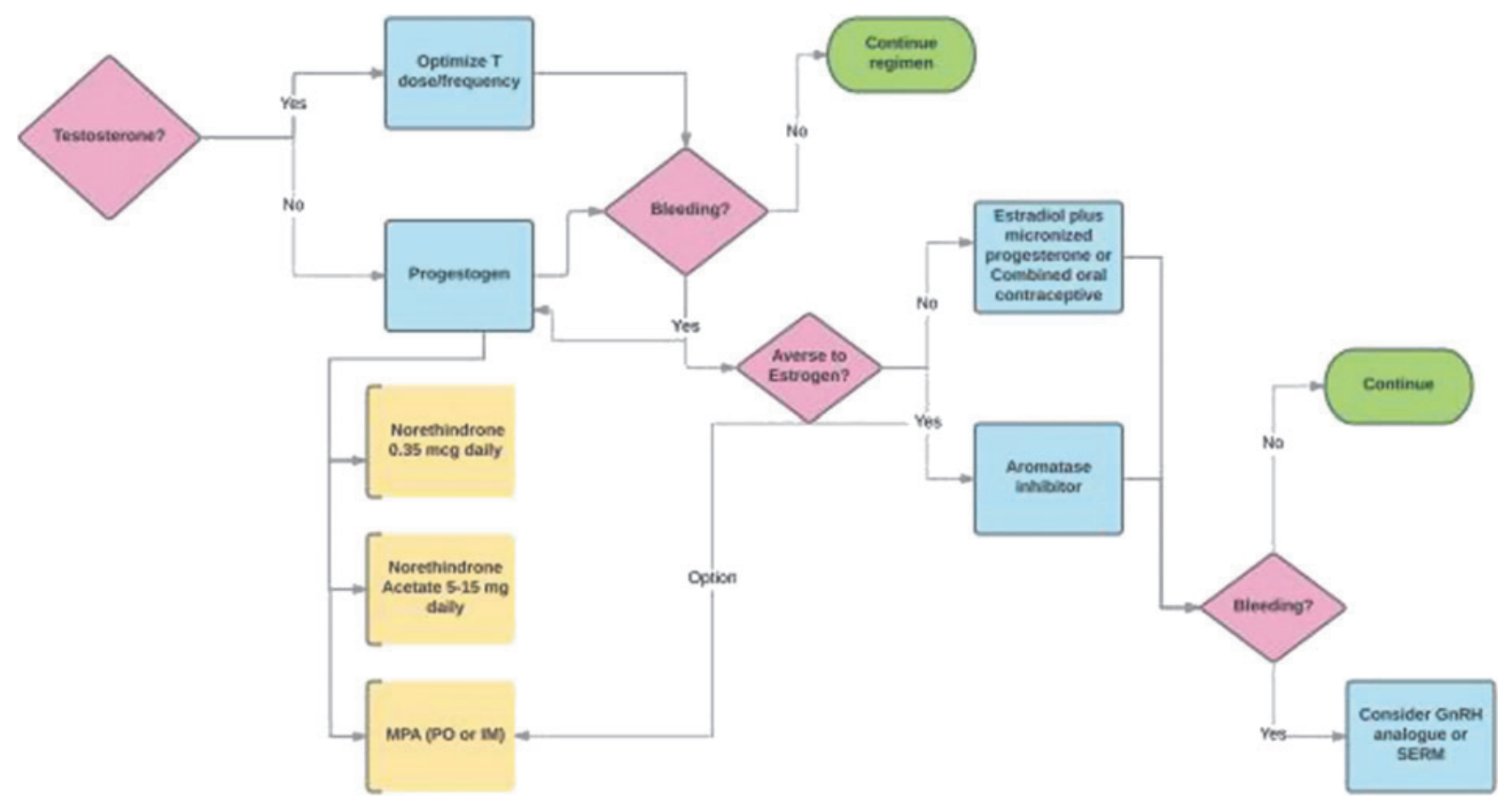

FIG. 1. A simplified flowchart for inducing and maintaining amenorrhea. SERM, selective estrogen receptor modulators.

not present, people may experience symptoms similar to those seen in menopause such as hot flashes. We do not recommend routine use in patients who desire a prolonged agonadal state; the lack of sex steroids in these individuals is detrimental to bone health, as inferred by the observation that men without estrogen receptors and those with very delayed puberty have poor bone health. ${ }^{49,50}$

\section{Hysterectomy}

Performed with or without salpingectomy/oophorectomy, this is a definitive option for the elimination of uterine bleeding. Hysterectomy may be performed abdominally, laparoscopically, robotically, or transvaginally. ${ }^{51}$ Current guidelines set forth by the World Professional Association for Transgender Health recommend persistent, well-documented gender dysphoria, the capacity to make a fully informed decision and consent to treatment, well-controlled mental health or medical concerns if significant, and 1 year of genderaffirming hormones unless not desired or medically contraindicated for the individual. ${ }^{51}$ Additionally it is recommended that the patient be the age of majority and have two letters of referral from mental health professionals. ${ }^{52}$ The Endocrine Society Practice Guidelines recommend the risks and benefits be evaluated by the individual. ${ }^{12}$ In the National Transgender Discrimination Survey, $21 \%$ of transmen surveyed had undergone hysterectomy, 58\% desired a hysterectomy at some time in the future, and $21 \%$ had no desire for a hysterectomy. ${ }^{53}$

\section{Conclusion}

Management of uterine bleeding is vital for the mental health of the transmasculine or nonbinary patient who desires amenorrhea. Our typical work flow is presented in Figure 1. Progestogens may be initiated early in medical transition if they are not ready for or not desiring testosterone. If, while on testosterone amenorrhea is not achieved, a trial of an increased dose or change in dose frequency is usually the first step. For persistent bleeding, particularly in the obese individual, a trial of an AI may be beneficial. Other options remain viable, but a decision to utilize them must be the result of an informed discussion and consent between the treating physician and patient.

\section{Acknowledgment}

The authors would like to thank Norman Spack, $\mathrm{MD}$, for his expert guidance, patience, and wisdom in treating adolescent patients and imparting his knowledge. 


\section{Author Disclosure Statement}

No competing financial interests exist.

\section{References}

1. Illingworth P. Amenorrhea, anovulation, and dysfunctional uterine bleeding. In: Endocrinology: Adult and Pediatric, 6th ed. (Jameson IL, De Groot LJ; eds). Philadelphia: Saunders Elsevier, 2010, pp. 2341-2355.

2. Fraser I. Regulating menstrual bleeding. J Reprod Med. 1999;44:158-164.

3. Campbell S, Cameron IT. The origins and physiology of menstruation. In: Clinical Disorders of the Endometrium and Menstrual Cycle. (Cameron IT, Fraser IS, Smith SK; eds). Oxford: Oxford University Press, 1998, pp. 13-30.

4. Marshall JC, Rame NK. Hormonal regulation of the menstrual cycle, mechanisms of ovulation, premenstrual syndromes. In: Endocrinology: Adult and Pediatric, 6th ed. (Jameson IL, De Groot LJ; eds). Philadelphia: Saunders Elsevier, 2010, pp. 2327-2340.

5. The American College of Obstetricians and Gynecologists: diagnosis of abnormal uterine bleeding in reproductive aged women. Practice Bulletin No. 128. American College of Obstetricians and Gynecologists. Obstet Gynecol. 2012;120:197-206.

6. Nakamura A, Watanabe $M$, Sugimoto $M$, et al. Dose-response analysis of testosterone replacement therapy in patients with female to male gender identity disorder. Endocr J. 2013;60:275-281.

7. Spratt DI, Stewart I, Savage C, et al. Subcutaneous injection of testosterone is an effective and preferred alternative to intramuscular injection: demonstration in female-to-male transgender patients. J Clin Endocrinol Metab. 2017;102:2349-2355.

8. Grynberg M, Fanchin R, Dubost G, et al. Histology of genital tract and breast tissue after long-term use testosterone administration in a femaleto-male transsexual population. Reprod Biomed Online. 2010;20:553-558.

9. Perrone AM, Cerpolini S, Maria Salfi NC, et al. Effect of long-term testosterone administration on the endometrium of female-to-male (FtM) transsexuals. J Sex Med. 2009;6:3193-3200.

10. Loverro $G$, Resta $L$, Dellino $M$, et al. Uterine and ovarian changes during testosterone administration in young female-to-male transsexuals. Taiwan J Obstet Gynecol. 2016;55:686-691.

11. Light AD, Obedin-Maliver J, Sevellius JM, Kerns JL. Transgender men who experienced pregnancy after female-to-male gender transitioning. Obstet Gynecol. 2014;124:1120-1127.

12. Hembree WC, Cohen-Kettenis P, Delemarre-van de Waal HA, et al. Endocrine treatment of transsexual persons: an Endocrine Society clinical practice guideline. J Clin Endocrinol Metab. 2009;94:3132-3154.

13. Pfizer. Product Information: PROVERA(R) oral tablets, medroxyprogesterone acetate oral tablets. New York, NY: Pharmacia and Upjohn Company (Per Daily Med), 2009.

14. Moyer DL, de Lignieres D, Driguez P, Pez JP. Prevention of endometrial hyperplasia by progesterone during long-term estradiol replacement: influence of bleeding pattern and secretory changes. Fertile Steril. 1993;59:992-997.

15. Moyer DL, Felix JC. The effects of progesterone and progestins on endometrial proliferation. Contraception. 1998;57:399-403.

16. Gillet JY, Andre G, Vaguer B, et al. Induction of amenorrhea during hormone replacement therapy; optimal micronized progesterone dose. A multicenter study. Maturitas. 1994;19:103-115.

17. Giudice LC. Genes associated with embryonic attachment and implantation and the role of progesterone. J Reprod Med. 1999;44(2 suppl):165-171.

18. Deligdisch L. Hormonal pathology of the endometrium. Mod Pathol. 2000;13:285-294.

19. Lynch MM, Khandheria MM, Meyer WJ. A retrospective study of the management of childhood and adolescent gender identity disorder using medroxyprogesterone acetate. Intl J Transgenderism. 2015;16: 201-208.

20. McCann MF, Potter LS. Progestin-only oral contraception: a comprehensive review. Contraception. 1994;50:S1-S195.

21. Barbosa I, Bakos O, Olsson SE, et al. Ovarian function during use of a levonorgestrel-releasing IUD. Contraception. 1990;42:51-66.

22. Lähteenmäki $\mathrm{P}$, Jukarainen $\mathrm{H}$. Novel delivery systems in contraception. $\mathrm{Br}$ Med Bull. 2000;56:739-748.

23. Fraser IS, Hickey M, Song JY. A comparison of mechanisms underlying disturbances of bleeding caused by spontaneous dysfunctional uterine bleeding or hormonal contraception. Hum Reprod. 1996;11(suppl 2): 165-178.

24. Stanczyk FZ. Structure-function relationships, potency and pharmacokinetics of progestogens. In: Treatment of the Postmenopausal Woman, Basic and Clinical Aspects. (Lobo RA, ed.) New York: Raven Press, 1994.

25. Cundy $T$, Evans $M$, Roberts $H$, et al. Bone density in women receiving depot-medroxyprogesterone acetate for contraception. BMJ. 1991; 303:13-16.

26. Scholes $D$, LaCroix AZ, Ott SM, et al. Bone mineral density in women using depot medroxyprogesterone acetate for contraception. Obstet Gynecol. 1999:93:233-238.

27. Guilbert ER, Brown JP, Kaunitz AM, et al. The Use of depotmedroxyprogesterone acetate in contraception and its potential impact on skeletal health. Contraception. 2009;79:167-177.

28. World Health Organization. Department of Reproductive Health and Research. WHO statement on hormonal contraception and bone health. Wkly Epidemiol Rec. 2005;35:302-304.

29. Cromer BA, Scholes D, Berenson A, et al. Depot medroxyprogesterone acetate and bone mineral density in adolescents-the black box warning: a position paper of the Society for Adolescent Medicine. J Adolesc Health. 2006;28:305-315.

30. Apgar BS, Greenberg G. Using progestins in clinical practice. Am Fam Physician. 2000;62:1839-1846.

31. Ottosson UB, Johansson BG, von Schoultz B. Subfractions of high-density lipoprotein cholesterol during estrogen replacement therapy: a comparison between progestogens and natural progesterone. Am J Obstet Gynecol. 1985;151:746-750.

32. Sherwin BB. The impact of different doses of estrogen and progestin on mood and sexual behavior in postmenopausal women. J Clin Endocrinol Metab. 1991;72:336-343.

33. Speroff L, Glass RH, Kase NG. Oral contraception. In: Clinical Gynecologic Endocrinology and Infertility, 7th ed. (Speroff L, Fritz M, eds). Philadelphia: Lippincott Williams \& Wilkins, 2005:Chapter 22 (accessed online).

34. Nelson LR, Bulun SE. Estrogen production and action. J Am Acad Dermatol. 2001;45:S116-S124.

35. Chumsri $\mathrm{S}$, Howes $\mathrm{T}$, Bao $\mathrm{T}$, et al. Aromatase, aromatase inhibitors, and breast cancer. J Steroid Biochem Mol Biol. 2011;125:13-22.

36. de Ronde W, de Jong FH. Aromatase inhibitors in men: effects and therapeutic options. Reprod Biol Endocrinol. 2011;9:93-99.

37. Shulman DI, Francis GL, Palmert MR, Eugster EA. Use of aromatase inhibitors in children and adolescents with disorders of growth and adolescent development. Pediatrics. 2008;121:e975-e983.

38. Onstad MA, Schmandt RE, Lu KH. Addressing the role of obesity in endometrial cancer risk, prevention, and treatment. J Clin Oncol. 2016:34:4225-4230.

39. Maximov PY, Lee TM, Jordan VC. The discovery and development of selective estrogen receptor modulators (SERMS) for clinical practice. Curr Clin Pharmacol. 2013;8:135-155.

40. Polin SA, Ascher SM. The effect of tamoxifen on the genital tract. Cancer Imaging. 2008;8:135-145.

41. Martinkovich S, Shah D, Planey SL, Arnott JA. Selective estrogen receptor modulators: tissue specificity and clinical utility. Clin Interv Aging. 2014;9:1437-1452.

42. Lapid O, van Wingerden JJ, Perleuter L. Tamoxifen therapy for the management of pubertal gynecomastia: a systematic review. J Pediatr Endocrinol Metab. 2013;26:803-807.

43. Kreher NC, Eugster EA, Shankar RR. The use of tamoxifen to improve height potential in short pubertal boys. Pediatrics. 2005;116:1513-1515.

44. Eugster EA, Shankar R, Feezle LK, Pescovitz OH. Tamoxifen treatment of progressive precocious puberty in a patient with McCune-Albright syndrome. J Pediatr Endocrinol Metab. 1999;12:681-686.

45. Eugster EA, Rubin SD, Reiter EO, et al.; McCune-Albright Study Group. Tamoxifen treatment for precocious puberty in McCune-Albright syndrome: a multicenter trial. J Pediatr. 2003;143:60-66.

46. Carel JC, Eugster EA, Rogol A, et al. Consensus statement on the use of gonadotropin-releasing hormone analogs in children. Pediatrics. 2008; 123:e752-e762.

47. Vlot MC, Klink DT, den Heijer M, et al. Effect of pubertal suppression and cross-sex hormone therapy on bone turnover markers and bone mineral apparent density (BMAD) in transgender adolescents. Bone. 2017;95:11-19. 
48. Carel JC, Heger S, Partsch CJ, Sippell WG. Long-term outcome after depot gonadotropin-releasing hormone agonist treatment of central precocious puberty: final height, body proportions, body composition, bone mineral density, and reproductive function. J Clin Endocrinol Metab. 1999;84:4583-4590.

49. Finkelstein JS, Klibanski A, Neer RM. A longitudinal evaluation of bone mineral density in adult men with histories of delayed puberty. J Clin Endocrinol Metab. 1996;81:1152-1155.

50. Finkelstein JS, Neer RM, Biller BM, et al. Osteopenia in men with a history of delayed puberty. N Engl J Med. 1992;326:600-604.

51. American College of Obstetricians and Gynecologists (ACOG) Committee on Gynecologic Practice. ACOG Committee Opinion No. 444: choosing the route of hysterectomy for benign disease. Obstet Gynecol. 2009;114:1156-1158.

52. World Professional Association for Transgender Health (WPATH). Standards of Care for the Health of Transsexual, Transgender, and Gender Nonconforming People, 7th Version. WPATH, 2012.

53. National Center for Transgender Equality and the National Gay and Lesbian Task Force: National Transgender Discrimination Survey Report on health and health care Findings of a Study. 2010. www.thetaskforce.org/ static $\mathrm{html} /$ downloads/resources and tools/ntds report_on health.pdf Accessed July 15, 2017.
Cite this article as: Carswell JM, Roberts SA (2017) Induction and maintenance of amenorrhea in transmasculine and nonbinary adolescents, Transgender Health 2:1, 195-201, DOI: 10.1089/ trgh.2017.0021.

\author{
Abbreviations Used \\ $\mathrm{Al}=$ aromatase inhibitors \\ $\mathrm{FSH}=$ follicle-stimulating hormone \\ $\mathrm{GnRH}=$ gonadotropin-releasing hormone \\ $\mathrm{GnRHa}=$ gonadotropin-releasing hormone agonists \\ $\mathrm{LH}=$ luteinizing hormone \\ SERMs $=$ selective estrogen receptor modulators
}

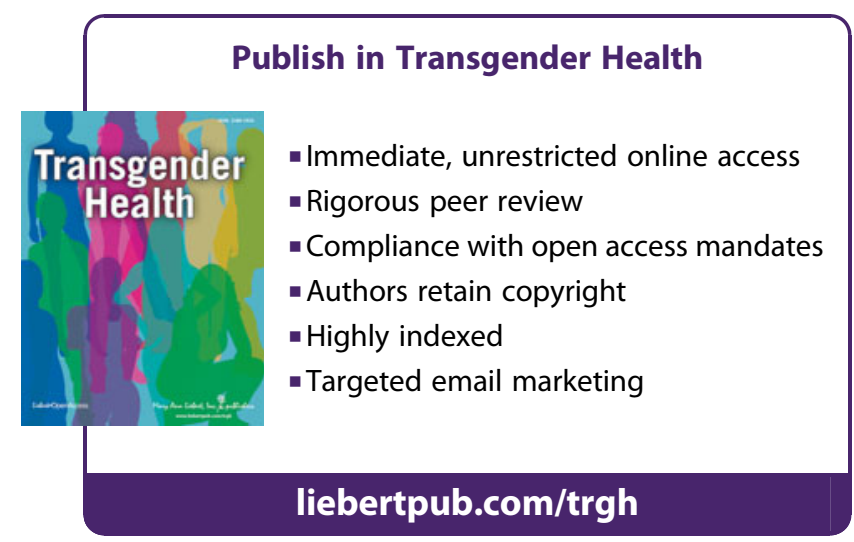

